\title{
Increasing West Nile virus antibody titres in central European plasma donors from 2006 to 2010
}

P O Rabel ${ }^{1,2}$, C B Planitzer ${ }^{1,2}$, M R Farcet ${ }^{1}$, K K Orlinger ${ }^{1}$, R Ilk ${ }^{1}$, P N Barrett ${ }^{1}$, T R Kreil (thomas_kreil@baxter.com) ${ }^{1}$

1. Baxter BioScience, Vienna, Austria

2. These two authors contributed equally to this work

Rabel PO, Planitzer CB, Farcet MR, Orlinger KK, Ilk R, Barrett PN, Kreil TR. Increasing West Nile virus antibody titres in central European plasma donors from 2006 to 2010. Euro Surveill. 2011;16(10):pii=19812. Available online: http://www.eurosurveillance.org/ViewArticle.aspx?Articleld=19812

Article published on 10 March 2011

We analysed by neutralisation assay 55 intravenous immunoglobulin preparations produced from human plasma collected in three central European countries, specifically Austria, Germany and the Czech Republic, from 2006 to 2010. The preparations from 2009 and 2010 contained increasing titres of neutralising antibodies against West Nile virus (WNV) in the absence of reported human WNV cases in these countries.

\section{Introduction}

Clinical cases of West Nile virus (WNV) infection in the European Union (EU) have so far been limited to sporadic outbreaks (Table), while serological studies in sentinel horses and birds, as well as humans, have shown WNV circulation for decades, particularly in the southern EU Member States [1]. However, as exemplified by the WNV outbreak in Greece in summer 2010, the pathogenicity of this virus for humans can change. A study in 2007 detected 1\% (4 of 392) WNV seropositivity in human serum samples collected from asymptomatic individuals living in Greece [2], whereas in 2010, WNV caused the second largest outbreak of human infections recorded in the EU since the outbreak in Romania in 1996 [3].

In order to assess how many people in central European countries may have been exposed to the virus, including individuals with subclinical disease, we analysed the WNV neutralising antibody titre of intravenous immunoglobulins (IVIG), a blood product containing pooled immunoglobulins from the plasma of more than a thousand donors from Austria, Germany and the Czech Republic. The suitability of this approach for assessing the cumulative number of WNV infections in a large donor population has recently been demonstrated through the use of IVIG to follow the spread of WNV in the United States [35].

\section{Methods and results}

Fully validated neutralisation assays were used to determine WNV and tick-borne encephalitis virus (TBEV) neutralisation titres $\left(\mathrm{NT}_{50}\right)$ in 55 individual lots of IVIG manufactured from plasma pools ( $\geq 1,000$ donors) collected in three EU countries (KIOVIG, Baxter), Austria (ca. 40-45\%), Germany (ca. 40-45\%) and to a lesser extent the Czech Republic (ca. 15\%). The IVIG lots tested were produced in the years $2006(n=10), 2007$ $(n=9), 2009(n=20)$ and $2010(n=16)$. For the year 2008, IVIG lots produced exclusively from EU plasma were not available for testing. The $\mathrm{NT}_{50}$ were determined, at least in duplicate, as described [35], using WNV strain 38599, lineage 1 or TBEV strain Neudoerfl. When tested against WNV, IVIG samples were used undiluted and titrated on Vero cells (ECACC 84113001); against TBEV, samples were initially diluted $1: 5$ and titrated on $A_{549}$ (ATCC CCL-185) cells. After seven days, each well was assessed for virus-induced cytopathic effect, and the $\mathrm{NT}_{50}$, i.e. the reciprocal dilution resulting in $50 \%$ virus neutralisation, is reported as mean \pm standard deviation of two or more replicates (Figure 1B). Plotting the WNV neutralisation titres of the respective IVIG lots against the year of product release, a statistically significant increase over the years 2006 to 2010 was observed $(p=0.0269$ one way ANOVA and $p=0.004$, post test for linear trend; Figure 1A).

To specifically discriminate antibodies induced by WNV infections of EU plasma donors from possibly crossreactive antibodies against TBEV, a Flavivirus related to WNV and widely endemic in central Europe, the TBEV neutralisation capacity of the IVIG lots was also determined, after the first lots with higher WNV activity had been detected. This was done for 30 of the 55 IVIG lots (Figure $1 \mathrm{~B}$ ). We assessed a potential contribution of TBEV neutralising antibody titres to the measured WNV antibody titres by correlation analysis and found a significant correlation $\left(r^{2}=0.5, p=0.002\right)$ between the TBEV and WNV neutralisation titres for 19 of 30 IVIG lots analysed (Figure 1B, open circles). The apparent WNV neutralisation capacity of the majority of IVIG lots produced from plasma collected in Austria, Germany and the Czech Republic therefore resulted, at least partially, from cross reactive antibodies as induced by the wide-spread use of TBEV vaccines or TBEV infections. The IVIG lots produced from plasma collected more recently, six lots in 2009 and five lots released for 2010 until April, did not fit this correlation. In general, plasma collection pre-dates release of IVIG lots 
TABLE

Cases of West Nile virus infection and seropositivity in EU countries, Russia and Israel, by year of occurrence, 1962-2010

\begin{tabular}{|c|c|c|c|c|c|c|c|c|}
\hline Year & Country & Cases & WNND & Fatalities & Seropositivity & CFR [\%] & Lineage & Reference \\
\hline $1962-1964$ & France & 13 & $\mathrm{NI}$ & 0 & $\mathrm{NI}$ & $\mathrm{NI}$ & $\mathrm{NI}$ & [4] \\
\hline 1973 & Portugal & $\mathrm{NI}$ & $\mathrm{NI}$ & $\mathrm{NI}$ & $\begin{array}{c}0.5 \% \\
(1,649 \text { sera anti-WNV-positive })\end{array}$ & $\mathrm{NI}$ & $\mathrm{NI}$ & [5] \\
\hline 1973 & Spain & $\mathrm{NI}$ & $\mathrm{NI}$ & $\mathrm{NI}$ & $\begin{array}{c}17 \% \\
\text { (701 sera anti-Flavivirus-positive) }\end{array}$ & $\mathrm{NI}$ & $\mathrm{NI}$ & [6] \\
\hline 1975-1979 & France & $\mathrm{NI}$ & $\mathrm{NI}$ & $\mathrm{NI}$ & $\begin{array}{c}5 \% \\
\text { (235 sera anti-WNV-positive) }\end{array}$ & $\mathrm{NI}$ & $\mathrm{NI}$ & [7] \\
\hline $1975-1976$ & Spain & $\mathrm{NI}$ & $\mathrm{NI}$ & $\mathrm{NI}$ & $\begin{array}{c}8 \% \\
(1,037 \text { sera anti-WNV-positive })\end{array}$ & $\mathrm{NI}$ & $\mathrm{NI}$ & [8] \\
\hline 1980 & Spain & $\mathrm{NI}$ & $\mathrm{NI}$ & $\mathrm{NI}$ & $\begin{array}{c}8 \% \\
\text { (130 sera anti-Flav-positive) }\end{array}$ & $\mathrm{NI}$ & $\mathrm{NI}$ & [9] \\
\hline 1982 & France & 1 & 1 & $\mathrm{NI}$ & $\mathrm{NI}$ & $\mathrm{NI}$ & $\mathrm{NI}$ & [10] \\
\hline 1996 & Romania & 393 & 352 & 17 & $\mathrm{NI}$ & 4 & 1 & $\begin{array}{l}{[11]} \\
{[12]} \\
{[13]} \\
{[14]}\end{array}$ \\
\hline 1997 & Czech Republic & 5 & 0 & 0 & $\begin{array}{c}2.1 \% \\
\text { (619 sera anti-WNV-positive) }\end{array}$ & $\mathrm{NI}$ & $\mathrm{NI}$ & [15] \\
\hline 1997-1998 & Romania & $\mathrm{NI}$ & 13 & 1 & $\begin{array}{c}4 \% \\
\text { (959 sera anti-WNV-positive) }\end{array}$ & $\mathrm{NI}$ & $\mathrm{NI}$ & $\begin{array}{l}{[12]} \\
{[16]}\end{array}$ \\
\hline 1999 & Czech Republic & 4 & $\mathrm{NI}$ & $\mathrm{NI}$ & $\mathrm{NI}$ & $\mathrm{NI}$ & $\mathrm{NI}$ & [15] \\
\hline 1999 & Czech Republic & $\mathrm{NI}$ & $\mathrm{NI}$ & $\mathrm{NI}$ & $\begin{array}{c}2 \% \\
\text { (619 sera anti-WNV-positive) }\end{array}$ & $\mathrm{NI}$ & $\mathrm{NI}$ & [15] \\
\hline 1999 & Russia & 318 & 84 & 40 & $\mathrm{NI}$ & 13 & 1 & $\begin{array}{l}{[11]} \\
{[17]} \\
{[18]}\end{array}$ \\
\hline 2000 & Russia & 56 & 20 & 0 & $\mathrm{NI}$ & $\mathrm{NI}$ & $\mathrm{NI}$ & $\begin{array}{l}{[12]} \\
{[17]}\end{array}$ \\
\hline 2000 & Israel & 417 & 307 & 35 & $\mathrm{NI}$ & 8 & $\mathrm{NI}$ & $\begin{array}{l}{[19]} \\
{[20]}\end{array}$ \\
\hline 2001 & Russia & 64 & $\mathrm{NI}$ & $\mathrm{NI}$ & $\mathrm{NI}$ & $5-10$ & $\mathrm{NI}$ & $\begin{array}{l}{[12]} \\
{[17]}\end{array}$ \\
\hline 2002 & Czech Republic & 1 & 0 & 0 & $\mathrm{NI}$ & $\mathrm{NI}$ & $\mathrm{NI}$ & [21] \\
\hline 2002 & Spain & $\mathrm{NI}$ & $\mathrm{NI}$ & $\mathrm{NI}$ & $\begin{array}{c}1 \% \\
\text { (797 sera anti-Flavivirus-positive) }\end{array}$ & $\mathrm{NI}$ & $\mathrm{NI}$ & [22] \\
\hline 2003 & France & 4 & 2 & 0 & $\mathrm{NI}$ & $\mathrm{NI}$ & $\mathrm{NI}$ & [23] \\
\hline 2003 & Hungary & $\mathrm{NI}$ & 14 & 0 & $\mathrm{NI}$ & $\mathrm{NI}$ & $\mathrm{NI}$ & [24] \\
\hline 2007 & Greece & $\mathrm{NI}$ & $\mathrm{NI}$ & $\mathrm{NI}$ & $\begin{array}{c}1.02 \% \\
\text { (4 sera anti-WNV-positive) }\end{array}$ & $\mathrm{NI}$ & $\mathrm{NI}$ & [2] \\
\hline 2007 & Russia & 54 & $\mathrm{NI}$ & 2 & $\mathrm{NI}$ & 4 & 2 & {$[25]$} \\
\hline 2008 & Hungary & $\mathrm{NI}$ & 14 & 0 & $\mathrm{NI}$ & $\mathrm{NI}$ & $\mathrm{NI}$ & {$[26]$} \\
\hline 2008 & Italy & 13 & 8 & 0 & $\mathrm{NI}$ & $\mathrm{NI}$ & $\mathrm{NI}$ & $\begin{array}{l}{[27]} \\
{[28]}\end{array}$ \\
\hline 2009 & Italy & $\mathrm{NI}$ & 17 & 3 & $\mathrm{NI}$ & $\mathrm{NI}$ & 1 & $\begin{array}{l}{[29]} \\
{[30]}\end{array}$ \\
\hline 2010 & Hungary & 3 & $\mathrm{NI}$ & $\mathrm{NI}$ & $\mathrm{NI}$ & $\mathrm{NI}$ & $\mathrm{NI}$ & [31] \\
\hline 2010 & Russia & 448 & 26 & 6 & $\mathrm{NI}$ & 1 & $\mathrm{NI}$ & $\begin{array}{l}{[25]} \\
{[32]}\end{array}$ \\
\hline 2010 & Romania & 41 & $\mathrm{NI}$ & 4 & $\mathrm{NI}$ & 10 & $\mathrm{NI}$ & $\begin{array}{l}{[25]} \\
{[31]}\end{array}$ \\
\hline 2010 & Greece & 261 & 191 & 35 & $\begin{array}{c}1.5 \% \\
\text { (392 sera anti-WNV-positive) }\end{array}$ & 18 & 2 & $\begin{array}{l}{[31]} \\
{[33]} \\
{[34]}\end{array}$ \\
\hline
\end{tabular}

CFR: case fatality rate; NI: no information available; WNND: case with West Nile neuroinvasive disease; WNV: West Nile virus. 


\section{FIGURE 1}

West Nile virus and tick-borne encephalitis virus neutralisation by intravenous immunoglobulin lots produced from plasma collected in Austria, Germany and the Czech Republic $(\mathrm{N}=55)$
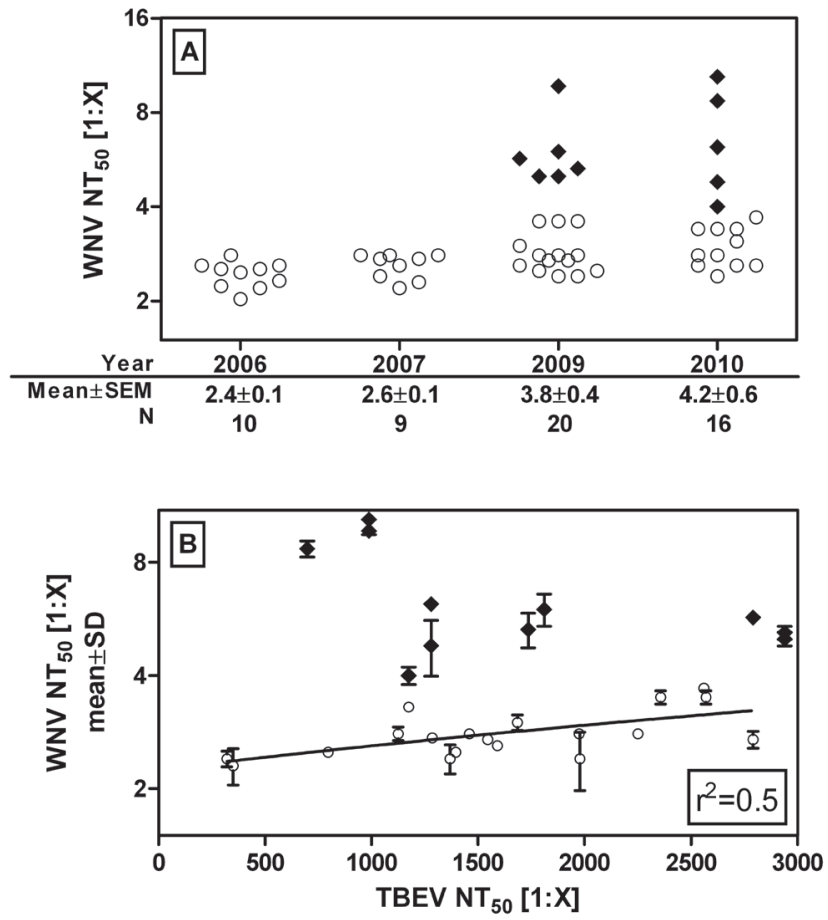

IVIG: intravenous immunoglobulins; $\mathrm{NT}_{50}$ : the reciprocal dilution resulting in $50 \%$ virus neutralisation; TBEV: tick-borne encephalitis virus; SD: standard deviation; SEM: standard error of the means; WNV: West Nile virus.

A: WNV neutralisation titres determined in IVIG lots produced between 2006 and 2010. WNV neutralisation titres within (open circles) and out of (black diamonds) the correlation slope as shown in B. Oneway ANOVA analysis revealed a systematic $(p=0.0269)$ mean increase in $\mathrm{NT}_{50}$ of IVIG sorted by production year.

B: Correlation analysis $\left(r^{2}=0.5, p=0.002\right)$ of EU plasma-derived IVIG lots $(\mathrm{N}=30)$ tested at least in duplicate for WNV and TBEV neutralisation. Results are given as mean $\mathrm{NT}_{50} \pm \mathrm{SD}$.

IVIG lots exclusively collected from EU plasma were not available for the year 2008 . by approximately 6-8 months. The IVIG lots containing significantly higher WNV-neutralising capacity (Figure 1 , black diamonds) did not follow a seasonal pattern.

The non-structural flavivirus protein $\mathrm{NS}_{1}$ is only expressed during infection, but not present in the inactivated whole virus vaccines that are used in the countries analysed here. In addition, reactivity of antibodies with the NS1 protein is specific to the flavivirus serotype, and thus infections with either WNV or TBEV can be differentiated [36]. We therefore analysed the antibody specificity of six randomly selected IVIG lots, produced in $2007(\mathrm{n}=1)$ and $2009(\mathrm{n}=5)$, by Western blot. TBEV- or WNV-infected Vero cells as well as recombinant WNV NS1 antigen were used as a positive and uninfected Vero cells as a negative control $[37,38]$. The blots were incubated with IVIG produced from plasma collected in Austria, Germany and the Czech Republic (Figure $2 \mathrm{~A}$ ), or with a control serum from TBEV-infected mice (Figure 2B). IVIG interacted with the flavivirus structural envelope protein $E$ as well as the WNV-specific NS1 (Figure 2A). In contrast, the control mouse serum reacted strongly only with the $E$ protein of TBEV-infected cells and weakly with WNVinfected cells (Figure 2B).

\section{Discussion and conclusion}

We found that IVIG preparations manufactured from plasma collected in Austria, Germany and the Czech Republic, contained neutralising antibodies against WNV at titres which have increased significantly since 2009. As WNV and TBEV are related flaviviruses, albeit distantly, we quantified neutralising antibody titres against TBEV in these IVIG lots, to investigate crossreactivity between these two viruses as a potentially confounding variable. Indeed, very high TBEV NT titres of between 400 and 3,000 were observed in all

\section{FIGURE 2}

Reactivity of intravenous immunoglobulin lots produced from plasma collected in Austria, Germany and the Czech Republic with viral proteins
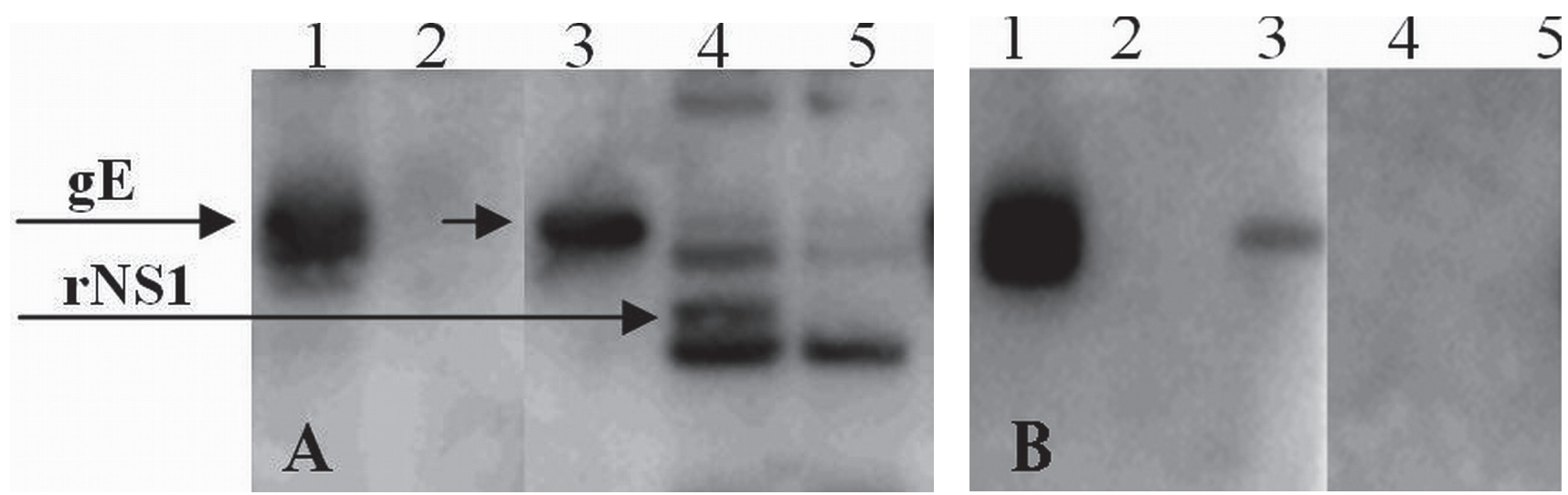

HRP: horseradish peroxidise; IVIG: intravenous immunoglobulins; $\mathrm{NT}_{50}$ : the reciprocal dilution resulting in $50 \%$ virus neutralisation; $\mathrm{TBEV}$ : tick-borne encephalitis virus; PVDF: polyvinylidene fluoride; SD: standard deviation; SDS PAGE: sodium dodecyl sulfate polyacrylamide gel electrophoresis; WNV: West Nile virus.

SDS PAGE transferred to Immobilon PVDF membranes and probed with (A) EU IVIG (1:10; WNV NT 50 mean \pm SD: $1.6 \pm 1.2, n=4)$ and HRP-coupled anti-human IgG (1:10,000) or (B) with TBEV-infected mouse serum (1:200) and HRP-conjugated anti-mouse IgG (1:10,000).

Lanes 1: Supernatants of TBEV-infected Vero cells; lanes 2: uninfected Vero cells (negative control); lanes 3: WNV-infected Vero cells, lanes 4: E.coli-expressed recombinant NS1 (positive control).

The figure shows one representative result of six IVIG lots tested. 
investigated years, a result of vaccination and possibly subclinical TBEV infections. Despite a significant correlation of TBEV and WNV neutralisation titres in approximately $60 \%$ of the IVIG lots, 11 of the 30 lots contained significantly higher ( $p<0.0001)$ neutralisation titres against WNV (mean \pm standard error of the means (SEM): 6.5 $\pm 0.6, n=11$, compared with $2.8 \pm 0.1$, $\mathrm{n}=19$ ) that did not correlate with the TBEV-neutralising capacity. IVIG lots produced from plasma collected in Austria, Germany and the Czech Republic were shown by Western Blot to contain specific antibodies against WNV NS1, the most useful differentiation marker for flavivirus infections in humans [36], which provided further evidence for past WNV infections in plasma donors from the central part of the EU. As the detection of antibodies to the WNV NS1 protein is serotype-specific, a possible contribution of antibodies against dengue virus can be excluded. The theoretical possibility of a contribution of neutralising antibodies to Usutu virus (USUV) [39], a virus that belongs to the same serocomplex as WNV, was not evaluated in vitro, as even the highest USUV activity in Austria as observed during the summer of 2003 [40] had no impact on the WNVspecific neutralisation titres in IVIG lots [41]. Moreover, despite a comprehensive surveillance programme for dead birds and mosquitoes in Austria [42], where around $45 \%$ of the plasma is collected for production of the IVIG lots tested in this study, no evidence of human exposure to USUV could be found [43], which makes a significant contribution of USUV antibodies to WNV neutralisation titres determined in the present study unlikely. However, additional studies would be relevant to describe this issue more precisely.

These results demonstrate WNV seropositivity in asymptomatic plasma donors from Austria, Germany and the Czech Republic, although some of the seropositivity could be due to travel-related infections. The present epidemiological situation in these countries is thus similar to the one in Greece before the recent epidemic. The causative agent of the outbreak in Greece, WNV lineage 2 , has only once before been isolated from humans with severe clinical progression, in an outbreak in Volgograd, Russia in 2007 [18]. Before those two outbreaks, this lineage was considered to be less virulent in humans compared to isolates belonging to the lineage 1 [44]. It has been suggested that the evolution from low to high human pathogenicity is associated with mutations of only a few amino acids, most likely in the non structural proteins [45].

The WNV neutralisation capacity of IVIG lots produced from Austria, Germany and the Czech Republic has increased from a mean $\mathrm{NT}_{50}$ of 2.5 in 2006 and 2007 to 4.2 at the beginning of 2010 , which accounts for an increase of 1.7 in the WNV neutralising capacity (Figure 1). The TBEV neutralisation titres of IVIG have not changed over time, and thus the increase in WNV neutralisation titres is most likely a true reflection of increased virus circulation. Using the same, fully validated assay, reconvalescent sera from human WNV cases in North America have earlier been shown to have a mean $\mathrm{NT}_{50}$ of 208 [41], 120-fold higher than the increase now observed. This would indicate past WNV exposure of just under $1 \%$ of the population of Austria, Germany and the Czech Republic. The increasing WNV seropositivity in these countries marks this virus as a potential public health concern in this area, and a future epidemic associated with human morbidity and mortality similar to that observed in summer 2010 in Greece cannot be excluded.

\section{Acknowledgements}

We are sincerely grateful to Jens Modrof for his continued support and scientific advice. The contributions of the entire Global Pathogen Safety Team, most notably Cornelia Lassl and Nicole Wurzer (WNV neutralisation testing), Sonja Kurzmann, Elisabeth Pinter, Karin Berka, Bettina York and Claudia Schwarr (virus propagation and cell culture) and the Molecular Vaccines Department, especially Kathrin Janecki (recombinant WNV NS1 expression) are gratefully acknowledged.

Conflict of interest

The authors of this manuscript have conflicts of interest to disclose: All authors were employees of Baxter AG and the work reported in this article was funded by Baxter AG.

\section{References}

1. Calistri P, Giovannini A, Hubalek Z, Ionescu A, Monaco $F$ Savini G, et al. Epidemiology of west nile in europe and in the mediterranean basin. Open Virol J. 2010;4:29-37.

2. Papa A, Perperidou P, Tzouli A, Castilletti C. West nile virusneutralizing antibodies in humans in Greece. Vector Borne Zoonotic Dis. 2010;10(7):655-8.

3. European Centre for Disease Prevention and Control. West Nile virus infection outbreak in humans in Central Macedonia, Greece: July-August 2010. Stockholm: ECDC; 2010. [Accessed March 2011]. Available from: http://www.ecdc.europa.eu/ en/publications/Publications/1001_MIR_West_Nile_virus infection_outbreak_humans_Central_Macedonia_Greece.pdf

4. Panthier R, Hannoun C, Beytout D, Mouchet J. [Epidemiology of West Nile virus. Study of a center in Camargue. 3.-Human diseases]. Ann Inst Pasteur. 1968;115(3):435-45.

5. Filipe AR. Serological survey for antibodies to arboviruses in the human population of Portugal. Trans R Soc Trop Med Hyg. 1974;68(4): 311-14

6. González MT, Filipe AR. Antibodies to arbovirus in northwestern Spain. Am JTrop Med Hyg. 1977;26(4):792-7.

7. Rollin PE, Rollin D, Martin P, Baylet R, Rodhain F, Hannoun C. Résultats d'enquêtes séroépidémiologiques récents sur les arboviroses en Camargue : populations humaines, equines, bovines et aviaires. [Results of recent seroepidemiological investigations on the arboviruses in the Camargue: human, equine, bovine and avian populations]. Medecine et Maladies Infectiouses 1982;12(2):77-80. French.

8. Filipe AR, de Andrade HR. Arboviruses in the Iberian Penynsula. Acta Virol. 1990;34(6):582-91.

9. Lozano A, Filipe AR. Anticuerpos frente a virus West Nile y otros virus transmitidos por artropodos en la poblacion del delta del Ebro. [Antibodies to West Nile and other arthropodborne viruses in the population of the Ebro delta]. Rev. Esp. Salud Pública, 1998;72(3):245-50. Spanish.

10. Leport C, Janowski M, Brun-Vezinet F, Rouzioux C, Rodhain F, Vilde JL. Meningo-myelo-encephalite a virus West NileInteret des dosages d'interferon dans les encephalitis primitives. [West Nile virus meningomyeloencephalitis--value of interferon assays in primary encephalitis]. Ann Med Interne. 1984;135(6):460-3. French

11. Hubalek Z, Savage HM, Halouzka J, Juricova Z, Sanogo YO, Lusk $\mathrm{S}$. West Nile virus investigations in South Moravia, Czechland. Viral Immunol. 2000;13(4):427-33.

12. Zeller, HG and Schuffenecker, I. West Nile virus: an overview of its spread in Europe and the Mediterranean basin in contrast 
to its spread in the Americas. Eur J Clin Microbiol Infect Dis. 2004;23(3):147-56.

13. Reiter, P. West Nile virus in Europe: understanding the present to gauge the future. Euro Surveill. 2010;15(10): pii=19508. Available from: http://www.eurosurveillance.org/ViewArticle. aspx?Articleld $=19508$

14. Cernescu C, Nedelcu NI, Tardei G, Ruta S, Tsai TF. Continued transmission of West Nile virus to humans in southeastern Romania, 1997-1998. J Infect Dis. 2000;181(2):710-2.

15. Hubalek Z, Halouzka J, Juricova Z. West Nile fever in Czechland. Emerg Infect Dis. 1999;5(4):594-5.

16. Tsai TF, Popovici F, Cernescu C, Campbell GL, Nedelcu NI. West Nile encephalitis epidemic in southeastern Romania. Lancet. 1998;352(9130):767-71.

17. Gerhardt R. West Nile virus in the United States (1999-2005). J Am Anim Hosp Assoc. 2006;42(3):170-7.

18. Platonov AE, Shipulin GA, Shipulina OY, Tyutyunnik EN, Frolochkina TI, Lanciotti RS, et al. Outbreak of West Nile virus infection, Volgograd Region, Russia, 1999. Emerg Infect Dis. 2001;7(1):128-32.

19. Weinberger M, Pitlik SD, Gandacu D, Lang R, Nassar F, Ben David D, et al. West Nile fever outbreak, Israel, 2000: epidemiologic aspects. Emerg Infect Dis. 2001;7(4):686-91.

20. Chowers MY, Lang R, Nassar F, Ben-David D, Giladi M, Rubinshtein,E, et al. Clinical characteristics of the West Nile fever outbreak, Israel, 2000. Emerg Infect Dis. 2001;7(4):675-8.

21. Hubálek Z, Lukácová L, Halouzka J, Sirůcek P, Januska J, Precechtelová J, et al. Import of West Nile virus infection in the Czech Republic. Eur J Epidemiol. 2006;21(4):323-4.

22. Opinion of the scientific committee on medicinal products and medical devices on "the impact of arthropod borne diseases (including WNV) on the safety of blood used for transfusion as well as organs used for transplantation in the European community". Brussels: European Commission, Health and Consumer Protection Directorate-General; 2003. C7 - Risk assessment C7/SANCO/SCMPMD/2003/00025 final D(03). [Accessed March 2011]. Available from: http://ec.europa.eu/ health/ph_risk/committees/scmp/documents/out49_en.pdf

23. Del Giudice P, Schuffenecker I, Vandenbos F, Counillon E, Zeller H. Human West Nile Virus, France. Emerg Infect Dis. 2004:10(10):1885-6.

24. Bakonyi T, Ivanics E, Erdelyi K, Ursu K, Ferenczi E, Weissenbock $\mathrm{H}$, et al. Lineage 1 and 2 strains of encephalitic West Nile virus, central Europe. Emerg Infect Dis. 2006;12(4):618-23.

25. ProMED-mail. West Nile virus - Eurasia (07): Russia, Romania. Archive Number: 20100922.3428. 23 September 2010. Available from: http://www.promedmail.org.

26. Krisztalovics K, Ferenczi E, Molnár Z, Csohán Á, Bán E, Zöldi $\mathrm{V}$, et al. West Nile virus infections in Hungary, AugustSeptember 2008. Euro Surveill. 2008;13(45):pii=19030. Available from: http://www.eurosurveillance.org/ViewArticle. aspx?Articleld $=19030$

27. Rizzo C, Vescio F, Declich S, Finarelli AC, Macini P, Mattivi A, et al. West Nile virus transmission with human cases in Italy, August - September 2009. Euro Surveill. 2009;14(40): pii=19353. Available from: http://www. eurosurveillance.org/ViewArticle.aspx?Articleld=19353

28. Gobbi F, Napoletano G, Piovesan C, Russo F, Angheben A, Rossanese A, et al. Where is West Nile fever? Lessons learnt from recent human cases in northern Italy. Euro Surveill. 2009;14(10):pii=19143. Available from: http://www. eurosurveillance.org/ViewArticle.aspx?Articleld=19143

29. Barzon L, Squarzon L, Cattai M, Franchin E, Pagni S, Cusinato $\mathrm{R}$, et al. West Nile virus infection in Veneto region, Italy, 2008-2009. Euro Surveill. 2009;14(31):pii=19289. Available from: http://www.eurosurveillance.org/ViewArticle. aspx?Articleld=19289

30. Angelini P, Tamba M, Finarelli AC, Bellini R, Albieri A, Bonilauri $P$, et al. West Nile virus circulation in EmiliaRomagna, Italy: the integrated surveillance system 2009. Euro Surveill. 2010;15(16):pii=19547. Available from: http://www. eurosurveillance.org/ViewArticle.aspx?Articleld=19547

31. ProMED-mail. West Nile Virus - Eurasia (2): Greece, Romania, Hungary. Archive Number: 20100907.3204. 7 Aug 2010. Available from: http://www.promedmail.org

32. ProMED-mail. West Nile Virus - Eurasia (09): Russia, Volgograd. Archive Number: 20101003.3582. 3 Oct 2010. Available from: http://www.promedmail.org

33. ProMED-mail. Encephalitis - Greece (06): (Central Macedonia), West Nile Virus Confirmed. Archive Number: 20100816.2843. 9 Aug 2010. Available from: http://www.promedmail.org

34. Danis K. Outbreak of West Nile Virus infection in Greece, 2010. Expert Consultation on West Nile Virus infection in Europe Thessaloniki, 25-26-13 January 2011. Hellenic Centre of Disease Control and Prevention. [cited 2011 Mar]. Available from: http://www.ecodev.gr/userfiles/file/pdf/Danis_WNV_ Greece2011.pdf

35. Planitzer CB, Modrof J, Yu MY, Kreil TR. West Nile virus infection in plasma of blood and plasma donors, United States. Emerg Infect Dis. 2009;15(10):1668-70.

36. Oceguera LF zrd, Patiris PJ, Chiles, RE, Busch MP, Tobler LH, Hanson CV. Flavivirus serology by Western blot analysis. Am Trop Med Hyg. 2007;77(1):159-63.

37. Orlinger KK, Holzer GW, Schwaiger J, Mayrhofer J, Schmid $\mathrm{K}$, Kistner $\mathrm{O}$, et al. An inactivated West Nile Virus vaccine derived from a chemically synthesized cDNA system. Vaccine. 2010;28(19):3318-24.

38. Chung KM, Liszewski MK, Nybakken G, Davis AE, Townsend $\mathrm{RR}$, Fremont $\mathrm{DH}$, et al. West Nile virus nonstructural protein NS1 inhibits complement activation by binding the regulatory protein factor $\mathrm{H}$. Proc Natl Acad Sci U S A. 2006;103(50):19111-6.

39. Cavrini F, Gaibani P, Longo G, Pierro AM, Rossini G, Bonilauri $P$, et al. Usutu virus infection in a patient who underwent orthotropic liver transplantation, Italy, August-September 2009 . Euro Surveill. 2009;14(50):pii=19448. Available from: http:// www.eurosurveillance.org/ViewArticle.aspx?Articleld $=19448$

40. Rubel F, Brugger K, Hantel M, Chvala-Mannsberger S, Bakonyi, $\mathrm{T}$, Weissenbock $\mathrm{H}$, et al. Explaining Usutu virus dynamics in Austria: Model development and calibration. Prev Vet Med. 2008;85(3-4):166-86.

41. Planitzer CB, Modrof J, Kreil TR. West Nile virus neutralization by US plasma-derived immunoglobulin products. J Infect Dis. 2007;196(3):435-40.

42. Chvala S, Bakonyi T, Bukovsky C, Meister T, Brugger K, Rubel $\mathrm{F}$, et al. Monitoring of Usutu virus activity and spread by using dead bird surveillance in Austria, 2003-2005. Vet Microbiol. 2007;122(3-4):237-45.

43. Weissenböck H, Kolodziejek J, Fragner K, Kuhn R, Pfeffer M, Nowotny N. Usutu virus activity in Austria, 2001-2002. Microbes Infect. 2003;5(12):1132-6.

44. Lanciotti RS, Ebel GD, Deubel V, Kerst AJ, Murri S, Meyer R, et al. Complete genome sequences and phylogenetic analysis of West Nile virus strains isolated from the United States, Europe, and the Middle East. Virology. 2002;298(1):96-105.

45. Botha EM, Markotter W, Wolfaardt M, Paweska JT, Swanepoel $\mathrm{R}$, Palacios $\mathrm{G}$, et al. Genetic determinants of virulence in pathogenic lineage 2 West Nile virus strains. Emerg Infect Dis. 2008;14(2):222-30. 